Article

\title{
Numerical and Experimental Investigation on Bonding Behavior of Cold Sprayed Porous WC-17Co Particles onto Different Substrates
}

\author{
Xinkun Suo ${ }^{1, *}$, Shuo Yin ${ }^{2}$, Hua $\mathrm{Li}^{1}$ and Rocco Lupoi ${ }^{2, *}$ \\ 1 Key Laboratory of Marine Materials and Related Technologies, Zhejiang Key Laboratory of Marine Materials \\ and Protective Technologies, Ningbo Institute of Materials Technology and Engineering, \\ Chinese Academy of Sciences, Ningbo 315201, China; lihua@nimte.ac.cn \\ 2 Department of Mechanical and Manufacturing Engineering, Trinity College Dublin, University of Dublin, \\ Parsons Building, Dublin 2, Ireland; yins@tcd.ie \\ * Correspondence: suoxinkun@nimte.ac.cn (X.S.); lupoir@tcd.ie (R.L.)
}

Received: 15 August 2018; Accepted: 15 October 2018; Published: 17 October 2018

\begin{abstract}
Cold sprayed WC-Co metal matrix composite coatings have shown great potential in wear-resistance applications. This work aims to use experimental and numerical methods to clarify the deposition and particle-substrate bonding behavior of a single porous WC-17Co particle onto various substrates. To achieve this objective, porous WC-17Co particles were used as the feedstock; soft Al 2024 (Al alloy) and hard stainless steel 316 (SS) were used as the substrates. The experimental results revealed that brittle WC-Co particles tended to remain intact after depositing on a soft $\mathrm{Al}$ alloy substrate, but underwent serious fracture when impacting on a hard SS substrate. Further results indicated that the high energy dissipation and the consequent high stress concentration in the WC-Co particle was the main reason for inducing the particle fracture. In addition, two different mechanical interlocking mechanisms were identified during the WC-Co particle deposition process (namely WC reinforcement interlock and WC-Co particle interlock), dominating the particle-substrate bonding. A soft $\mathrm{Al}$ alloy substrate resulted in better interlocking than a hard SS substrate, thereby the corresponding particle bonding ratio was also much higher.
\end{abstract}

Keywords: tungsten carbide; cobalt; kinetic spray; interlock; fracture; finite element

\section{Introduction}

WC-Co metal matrix composite (MMC) coatings have been widely used for preventing the underlying substrate materials from severe wear in aggressive environments. Fusion-based thermal spray technologies combined with agglomerated powders are primarily used to produce such WC-Co thin-films or coatings. During the thermal spray processes, the metallic Co matrix phase has to be completely melted upon impact to consolidate the agglomerated powders and to form the coating [1,2]. However, the substrate material's fusion always brings negative effects to the WC-Co coatings, such as decarburization, phase transformation and oxidation. These shortcomings significantly deteriorate the coating's mechanical properties and wear-resistance performance [1-4].

For the purposes of eliminating the adverse effects of the thermal spray technologies, much effort has been devoted to exploring alternative technology. Cold spray (also known as cold gas dynamic spray, kinetic spray or super particle deposition), as a low-temperature coating and additive manufacturing process, enables materials to be deposited without exceeding their melting temperatures. Cold sprayed coatings, therefore, greatly retain the original properties of their starting feedstock, effectively preventing the coating defects associated with high-temperature thermal spray processes [5]. Investigations on cold sprayed WC-Co coatings have been conducted during past 
decades. Existing studies have demonstrated that decarburization and phase transformation can be effectively avoided in cold sprayed WC-Co coatings due to the low working temperature [6-19]. This is a unique advantage that other thermal spray processes cannot achieve. Moreover, cold sprayed WC-Co coatings were also reported to possess high hardness (ranging from 800 to $2000 \mathrm{HV}$ ). Such high coating hardness is comparable to or even higher than that of thermal sprayed coatings $[8,10,12-15]$. In addition, cold sprayed WC-Co coatings also had excellent tribological performance. Compared with HVOF-sprayed WC-Co coatings, cold sprayed coatings had lower wear rate under both ball-on-disk sliding and dry abrasion tests $[10,12,13,16]$.

Single particle deposition experiment is of great importance to well understand the deposition and bonding features of a cold sprayed particle with a substrate [20]. In the case of cold sprayed WC-Co, single particle deposition was also conducted in some previous works [6,21-24]. It was reported that powder structure significantly affected the particle deposition behavior. High-porosity WC-Co particle was more likely to fracture during impact with the substrate due to poor cohesion strength $[21,25]$. As most parts of such fractured particles will rebound, the coating deposition efficiency of high-porosity WC-Co powders was relatively low. On the other hand, substrate hardness was also found to pose some impacts on the particle deposition behavior [6,21]. WC-Co particles were more difficult to deposit on hard substrates than on soft substrates [19]. Although existing studies have revealed some important phenomena involved in the single WC-Co particle deposition process, there are still many other issues to be clarified, such as the fundamental reasons for inducing WC-Co particle fracture and the dominant bonding mechanism between WC-Co particles and substrate. The objective of this paper is to use experimental and numerical methods to clarify the deposition and particle-substrate bonding features of a single WC-Co particle onto $\mathrm{Al}$ alloy and stainless-steel substrates.

\section{Experimental Methodology}

Agglomerated WC-17Co $(-48+10 \mu \mathrm{m}$, Xinke, Wuxi, China) powders with spherical shape were used as the feedstock. Figure 1 shows the surface morphology and cross-sectional view of a WC-Co particle observed by SEM (Carl Zeiss ULTRA, Oberkochen, Germany). The sizes of the carbides and the pores and the amount of the pores in the composite coatings, were acquired using image analysis, which was employed in the simulation model. Particles were deposited onto polished Al 2024 (Al alloy) and stainless steel 316 (SS) substrates using a self-developed cold spray system (Trinity College Dublin, Dublin, Ireland). The system consists of compressed nitrogen/helium gas from cylinders, gas heater, powder feeder, computer numerical control working platform for controlling the substrate movement, Laval nozzle and computer control system [23]. In this work, nitrogen at the pressure of $3.0 \mathrm{MPa}$ and temperature of $400{ }^{\circ} \mathrm{C}$ was applied as the propulsive gas for single WC-Co particle deposition. Nozzle standoff distance and traversal speed were set as $35 \mathrm{~mm}$ and $300 \mathrm{~mm} / \mathrm{s}$, respectively. For characterizing the deposition features of a single WC-Co particle on different substrates, the surface morphology and cross-sectional view of the deposited particles, and the surface morphology of the substrate surface were observed by SEM. The bonding ratio of WC-Co particles onto various substrates was calculated by the following equation, $B R=\frac{N_{\mathrm{D}}}{N_{\mathrm{D}}+N_{\mathrm{C}}}$, where $B R$ is the particle bonding ratio, $N_{D}$ is the number of deposited particles and $N_{C}$ is the number of craters. Data were selected from three different locations on each sample and then averaged. 


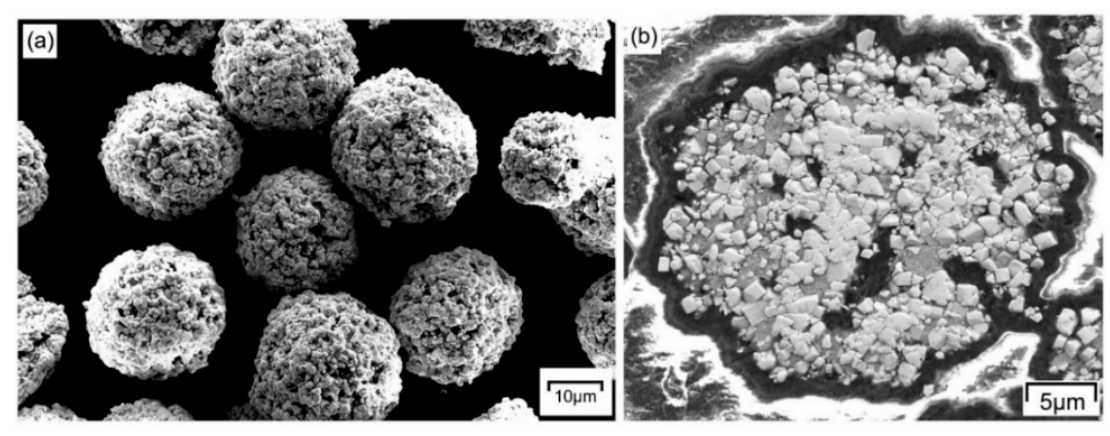

Figure 1. Surface morphology (a) and cross-sectional view (b) of the porous WC-17Co powders used in this work.

\section{Numerical Methodology}

A simplified finite element model, based on an ABAQUS platform (ver. 6.12), was employed to evaluate the deformation behavior of a single WC-Co particle. According to the details of the real powder used in the experiment, the WC-Co particle in the computational model was given a spherical shape with the diameter of $25 \mu \mathrm{m}$. Figure 2 shows the geometry and local meshing of the WC-17Co particle. Co was used as the matrix phase with a large amount of inclusive spherical WC reinforcements. The diameter of the WC reinforcement was defined as $0.5 \mu \mathrm{m}$. Five spherical pores with the diameter of $2 \mu \mathrm{m}$ were introduced in the WC-Co particle to roughly describe the porous structure. The particle and substrate were partitioned by the three-node triangular and four quadrilateral elements, respectively. Planar strain model with Lagrangian algorithm and dynamic explicit procedure was applied to build and solve the computational model. Fixed boundary condition was enforced to the substrate bottom and lateral. Contact process was implemented by using the surface-to-surface kinematic contact algorithm with balanced contact pair formulation. The substrate materials were described by the Johnson and Cook (JC) plasticity constitutive model, which accounts for strain, strain-rate hardening, as well as thermal softening. The JC parameters for Al alloy and SS can be found in References [26-28]. The matrix phase Co was described by isotropic plastic model; its elastic parameters were picked from Reference [29] and plastic data were collected from the real stress/strain curve in Reference [30]. The WC reinforcements were roughly considered to be rigid object and hence described by linear elastic model with a very high elastic modulus. Particle velocity and temperature were set as $528 \mathrm{~m} / \mathrm{s}$ and $211^{\circ} \mathrm{C}$ respectively, according to the computational result using Computational Fluid Dynamics (CFD).

(a)
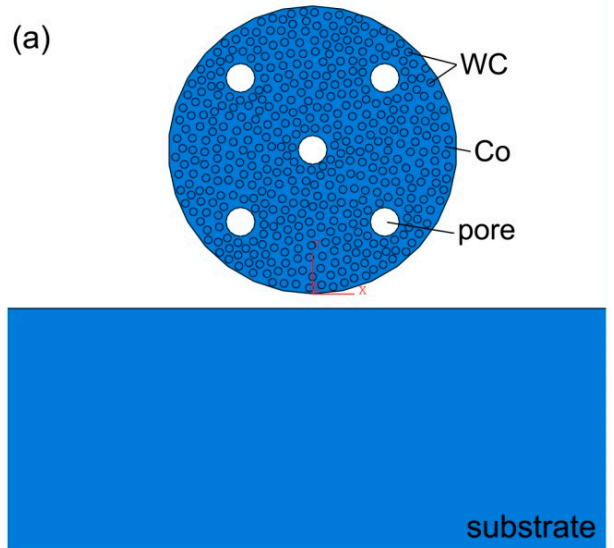

(b)
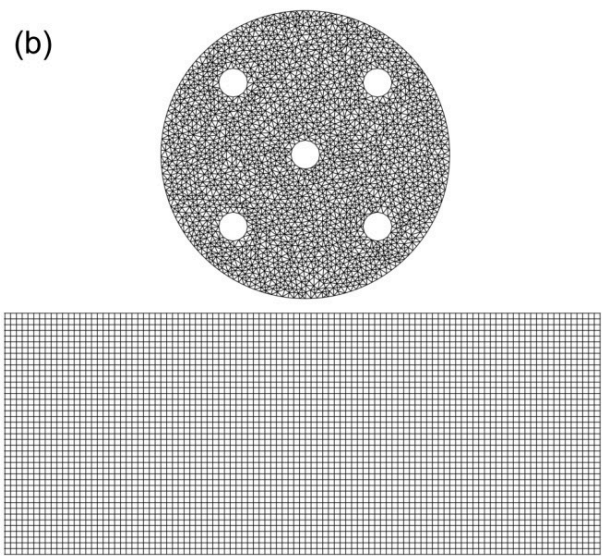

Figure 2. Geometry (a) and meshing (b) of the WC-Co particle used in the computation. 


\section{Results and Discussion}

\subsection{Deposition Features of a Single WC-Co Particle onto Al Alloy and SS Substrates}

Figure 3 shows the surface morphology of a WC-Co particle after deposition onto Al alloy and SS substrates. Clearly, the substrate materials posed significant impact on the particle deposition features. For the Al alloy substrate, the particle penetrated deeply and almost entirely embedded into it because most of the particle's kinetic energy was dissipated by soft Al alloy material through plastic deformation during the impact. In contrast, the SS substrate, due to the higher hardness, could not dissipate too much impact energy, only experiencing slight plastic deformation. This result is quite similar to the particle deposition feature as reported in Reference [6]. For further investigation, Figure 4 shows the cross-sectional view of a WC-Co particle after deposition onto Al alloy and SS substrates. It is noticed that the WC-Co particles experienced plastic deformation of varying degree in both cases. The plastic deformation was relative small compared to the ductile metals, which is probably due to the high triaxial stress state in the WC-Co particle [31]. Moreover, although both particles did not experience plastic deformation, their morphology after deposition exhibited obvious difference. The particle depositing on the Al alloy substrate retained a completely spherical shape. But the one depositing on the SS substrate suffered from serious fracture, showing many open cracks as marked by the white arrows and a long crack at the particle-substrate interface as marked by the white dotted line (Figures $3 b$ and $4 b$ ). The difference is also attributed to different substrate hardness. As addressed above, the soft $\mathrm{Al}$ alloy substrate could act as a buffer, dissipating most of the particle's kinetic energy. Therefore, the WC-Co particle itself did not absorb too much energy during the impact and retained its original status. However, for the SS substrate that only experienced slight deformation, the particle's kinetic energy was mostly imposed onto the particle. The WC-Co particle is very brittle, thereby its plastic deformation was prevented. In this respect, the impact energy can only be dissipated through fracture of the particle.
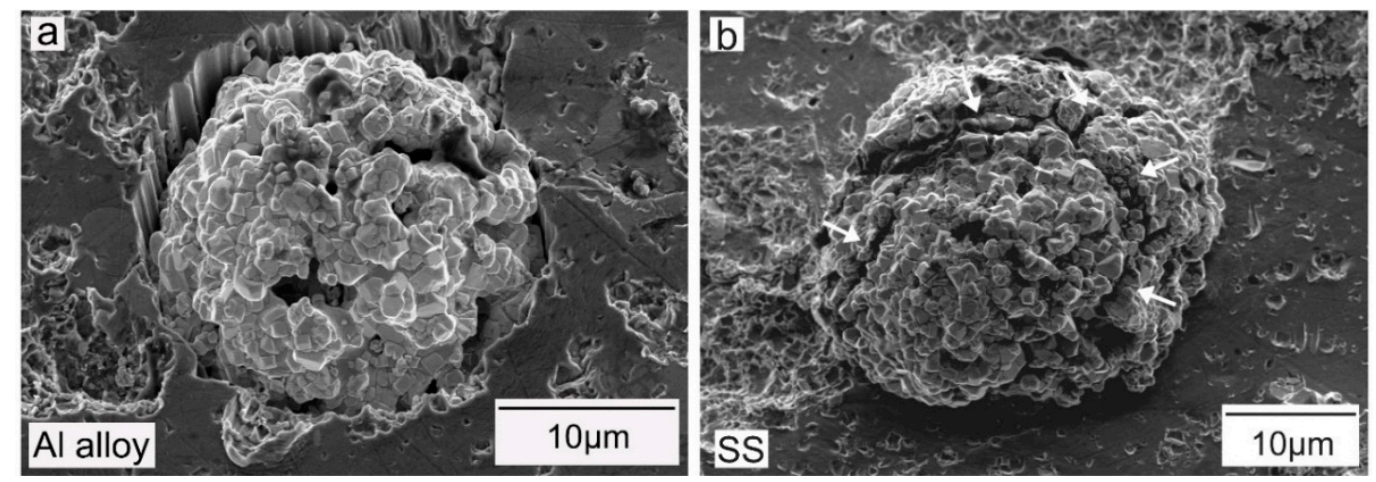

Figure 3. SEM imaging of surface morphology of a WC-Co particle after deposition on (a) Al alloy and (b) SS substrates.

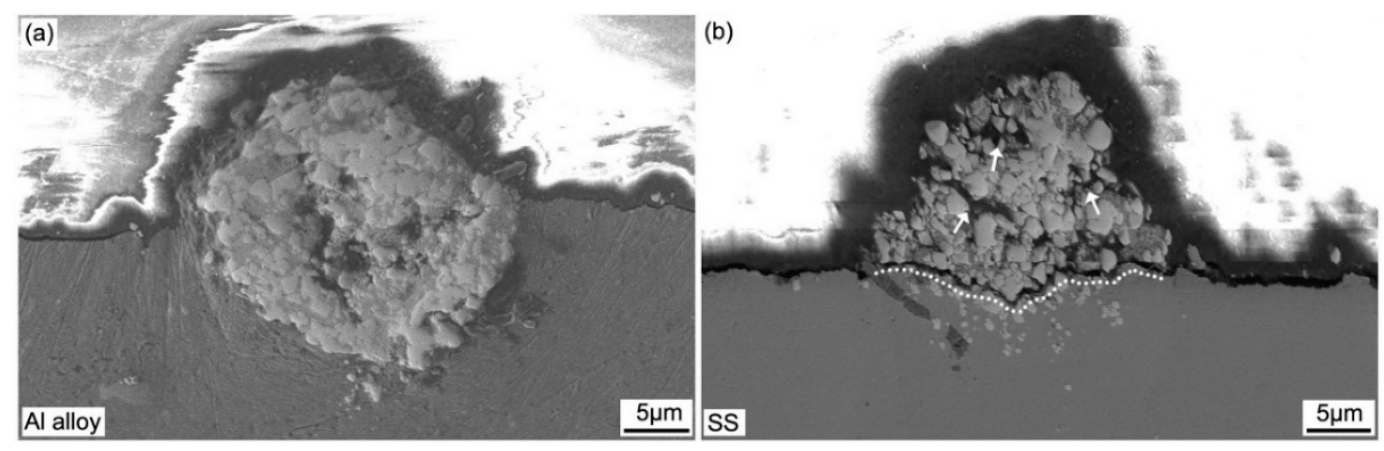

Figure 4. SEM imaging of cross-section of a WC-Co particle after deposition on (a) Al alloy and (b) SS substrates. 
In addition to the cracked particles as shown in Figures $3 b$ and $4 b$, Figure 5 shows more fracture modes of WC-Co particles after impacting onto SS substrate. Due to difference of particle kinetic energy and porosity and location in the particle, WC-Co particles experienced different fracture modes during deposition. Based on the fracture degree from low to high, fracture modes can be classified into three groups as shown Figure 5: Open crack, partly fractured and complete fracture. These fracture modes further demonstrate the role of substrate in the WC-Co particle deposition features. Furthermore, from Figure $5 c$, pores can be clearly seen on the fracture surface as marked by white arrows. This phenomenon may suggest that inner pores may be the weak point where fracture tends to take place.

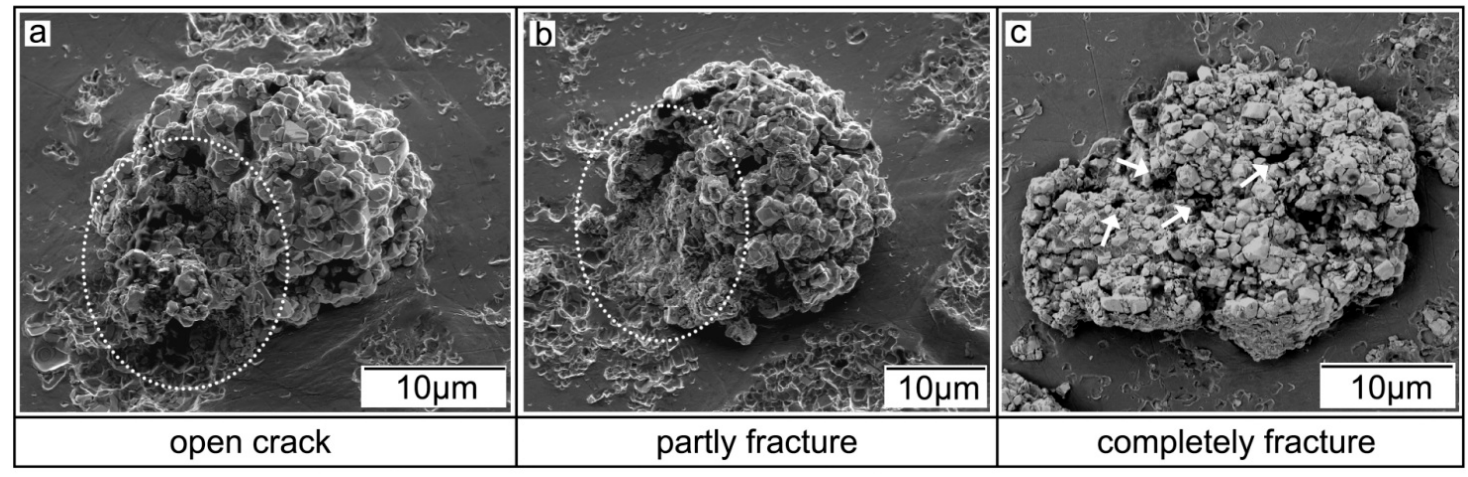

Figure 5. Various fracture modes of WC-Co particles after deposition on SS substrate: (a) Open crack, (b) partial fracture and (c) complete fracture.

\subsection{Modelling of a Single WC-Co Particle Impacting onto Al Alloy and SS Substrates}

For further understanding the fracture behavior of WC-Co particles upon impact, Figure 6 shows the simulated PEEQ (Equivalent Plastic Strain) distribution within the WC-Co particles that impacted onto $\mathrm{Al}$ alloy and SS substrates. Apparently, after being completely deformed, the $\mathrm{Al}$ alloy substrate experienced more prominent plastic deformation than the SS substrate, which accords with the experimental observation. Moreover, in both cases, due to the occurrence of stress concentration in the particle, the PEEQ mainly concentrated along the alignments of the particle inner pores. Most importantly, the particle on the SS substrate had much higher PEEQ than that on the Al alloy substrate, which clearly explained why fracture only took place in the particle depositing on the SS substrate. Fracture may take place from an inner pore, propagating along the stress concentration band to break the WC-Co particle $[32,33]$. This is consistent with the experimental observation in Figure $5 \mathrm{c}$ where many pores could be observed on the fracture surface. Note that the current simplified model does not consider the fracture of the WC-Co particle. In a realistic situation, a particle depositing on the SS substrate would already have fractured before experiencing such large plastic deformation.

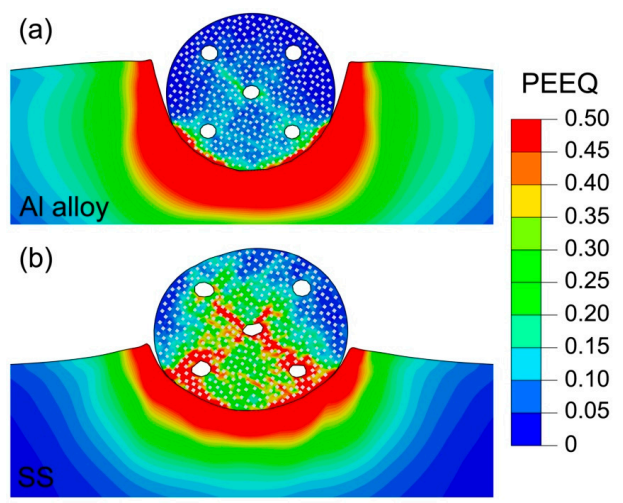

Figure 6. PEEQ distribution within a WC-Co particle after impact onto (a) Al alloy and (b) SS substrates. 


\subsection{Bonding Features of a Single WC-Co Particle onto Al Alloy and SS Substrates}

Figure 7 shows the SEM imaging of surface morphology of Al alloy and SS substrates after the impact of WC-Co particles. As can be seen, most of the WC-Co particles were successfully deposited on the $\mathrm{Al}$ alloy substrate and remained intact after impact. Some fractured particles can also be seen, which may be caused by either insufficient particle cohesion strength or the impact of the following incident particles. In contrast, on the SS substrate surface, many craters and only few fractured WC-Co particles were left after impact. It is hard to find an intact WC-Co particle; all deposited particles were seriously fractured. The bonding ratio measurement revealed that the soft $\mathrm{Al}$ alloy substrate led to a bonding ratio of $67.1 \%$, much higher than the SS substrate $(23.8 \%)$. In addition, many tiny particle debris were found to be trapped on the Al alloy substrate surface but they were not found on the SS substrate. These phenomena clearly demonstrated the superiority of soft Al alloy substrate for WC-Co particle deposition.
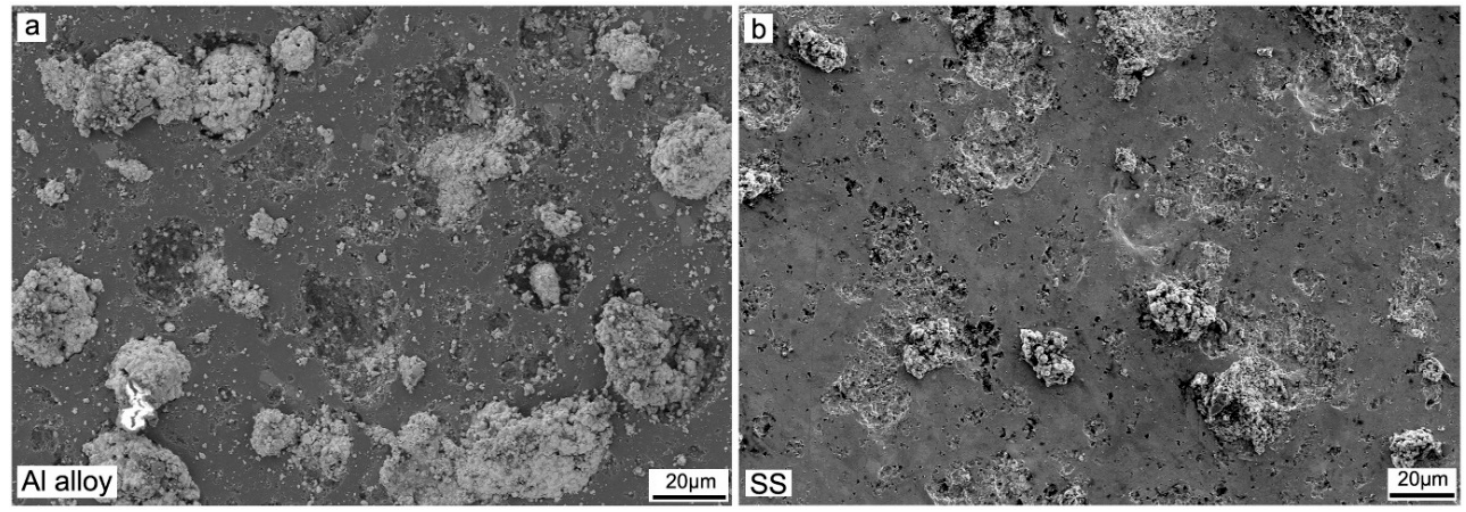

Figure 7. SEM imaging of substrate surface morphology after impacted by WC-Co particles: (a) Al alloy and (b) SS substrates.

It has been addressed in the above text that WC-Co particles were very brittle and almost underwent no plastic deformation during the deposition process. Under such a condition, adiabatic shear instability and the resultant temperature rise cannot occur in the Co phase of the WC-Co particles, which may significantly prevent the particle-substrate metallurgical bonding in both cases $[34,35]$. Therefore, there must be other mechanisms to dominate the higher bonding ratio of WC-Co particles on the $\mathrm{Al}$ alloy substrate than on the SS substrate. To clarify this, Figure 8 shows the SEM imaging of crater surface on Al alloy and SS substrates after the particle detached. The morphology of the crater surfaces on the $\mathrm{Al}$ alloy substrate showed significant difference from the cater on the SS substrate. A large number of WC reinforcements were found to be trapped by the Al alloy substrate material to form a kind of interlock bonding. Such interlocking would help to promote the particle-substrate bonding and the consequent particle bonding ratio. However, for the SS substrate, there are significantly less WC reinforcements trapped by the crater surface, which indicated the lack of such interlocking. On the other hand, for the highly deformed soft $\mathrm{Al}$ alloy substrate, the conventional particle-substrate mechanical interlocking also occurred much more easily compared with the hard SS substrate, which can further improve the particle-substrate bonding [7,36]. These facts clearly explained why the bonding ratio of WC-Co particles depositing onto the Al alloy substrate was higher than on the SS substrate. Based on the above discussion, it is also plausible to infer that the bonding between the WC-Co particle and the substrate may be dominated by mechanical interlocking. 

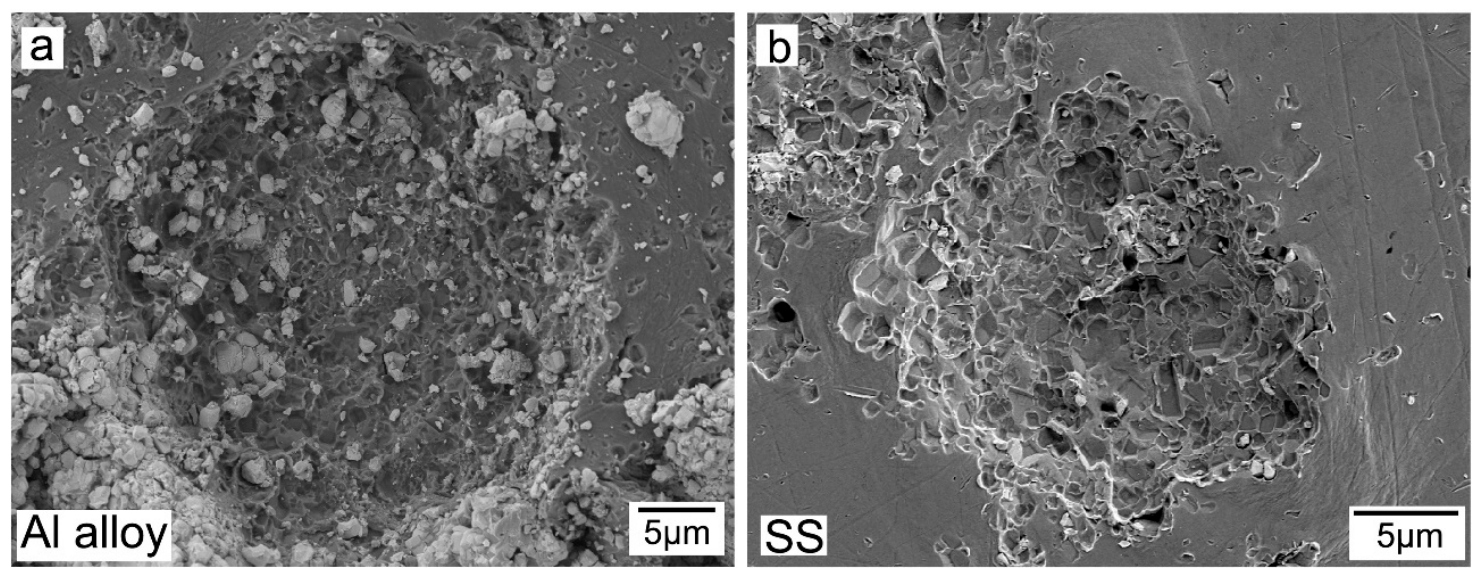

Figure 8. SEM imaging of craters on (a) Al alloy and (b) SS substrates.

\section{Conclusions}

In this work, the deposition and coating-substrate bonding behaviors of a single WC-17Co particle onto Al 2024 and SS 316 substrates were investigated by both experiments and numerical modelling. Based on the results and analysis, the following conclusions can be drawn:

Brittle WC-Co particles tended to remain intact after depositing on soft Al alloy substrate, but suffered from serious fracture when impacting on hard SS substrate, due to the differing hardness and energy dissipation.

The fracture of WC-Co particles during the deposition on SS substrate arose from the high energy dissipation and high stress concentration in the particle.

Mechanical interlocking may dominate the bonding between WC-Co particles and substrate. Soft $\mathrm{Al}$ alloy substrate resulted in better interlocking and thus higher particle bonding ratio than hard SS substrate.

Author Contributions: For research articles with several authors, a short paragraph specifying their individual contributions must be provided. The following statements should be used Conceptualization, X.S. and R.L.; Methodology, X.S.; Software, S.Y.; Validation, X.S. and S.Y.; Formal Analysis, X.S.; Writing-Original Draft Preparation, X.S.; Writing-Review \& Editing, H.L. and R.L.

Funding: This research was funded by National Natural Science Foundation of China (No. 21705158, No. 31500772), Key Research and Development Program of Zhejiang Province (No. 2015C01036, No. 2107C01003), International Scientific and Technological Cooperation Project of Ningbo (2017D10011), Zhejiang Provincial Natural Science Foundation of China (No. LY18C100003), 3315 Program of Ningbo for the financial support and Irish Research Council (GOIPD-2017-912).

Acknowledgments: The authors would like to thank the CRANN Advanced Microscopy Laboratory (AML) of Trinity College Dublin for their support in the analysis.

Conflicts of Interest: The authors declare no conflict of interest.

\section{References}

1. Li, C.-J.; Yang, G.-J. Relationships between feedstock structure, particle parameter, coating deposition, microstructure and properties for thermally sprayed conventional and nanostructured WC-Co. Int. J. Refract. Met. Hard Mater. 2013, 39, 2-17. [CrossRef]

2. Yang, T.; Wei, Q.; Qi, Y.; Wang, Y.; Xie, Y.; Luo, J.; Yu, Z. Microstructure evolution of thermal spray WC-Co interlayer during hot filament chemical vapor deposition of diamond thin films. J. Alloy Compd. 2015, 639, 659-668. [CrossRef]

3. Kumari, K.; Anand, K.; Bellacci, M.; Giannozzi, M. Effect of microstructure on abrasive wear behavior of thermally sprayed WC-10Co-4Cr coatings. Wear 2010, 268, 1309-1319. [CrossRef]

4. Ryu, T.; Sohn, H.Y.; Hwang, K.S.; Fang, Z.Z. Plasma synthesis of tungsten carbide and cobalt nanocomposite powder. J. Alloys Compd. 2009, 481, 274-277. [CrossRef]

5. Papyrin, A. Cold Spray Technology. Adv. Mater. Process. 2001, 159, 49-51. 
6. Dosta, S.; Bolelli, G.; Candeli, A.; Lusvarghi, L.; Cano, I.G.; Guilemany, J.M. Plastic deformation phenomena during cold spray impact of WC-Co particles onto metal substrates. Acta Mater. 2017, 124, 173-181. [CrossRef]

7. Yin, S.; Ekoi, E.J.; Lupton, T.L.; Dowling, D.P.; Lupoi, R. Cold spraying of WC-Co-Ni coatings using porous WC-17Co powders: Formation mechanism, microstructure characterization and tribological performance. Mater. Des. 2017, 126, 305-313. [CrossRef]

8. Kim, H.J.; Lee, C.H.; Hwang, S.Y. Fabrication of WC-Co coatings by cold spray deposition. Surf. Coat. Technol. 2005, 191, 335-340. [CrossRef]

9. Kim, H.J.; Lee, C.H.; Hwang, S.Y. Superhard nano WC-12\%Co coating by cold spray deposition. Mater. Sci. Eng. A 2005, 391, 243-248. [CrossRef]

10. Couto, M.; Dosta, S.; Guilemany, J.M. Comparison of the mechanical and electrochemical properties of WC-17 and 12Co coatings onto Al7075-T6 obtained by high velocity oxy-fuel and cold gas spraying. Surf. Coat. Technol. 2014, 180-189. [CrossRef]

11. Ang, A.S.M.; Berndt, C.C.; Cheang, P. Deposition effects of WC particle size on cold sprayed WC-Co coatings. Surf. Coat. Technol. 2011, 205, 3260-3267. [CrossRef]

12. Couto, M.; Dosta, S.; Fernández, J.; Guilemany, J.M. Comparison of the Mechanical and Electrochemical Properties of WC-25Co Coatings Obtained by High Velocity Oxy-Fuel and Cold Gas Spraying. J. Therm. Spray Technol. 2014, 23, 1251-1258. [CrossRef]

13. Wang, H.-T.; Chen, X.; Bai, X.-B.; Ji, G.-C.; Dong, Z.-X.; Yi, D.-L. Microstructure and properties of cold sprayed multimodal WC-17Co deposits. Int. J. Refract. Met. Hard Mater. 2014, 45, 196-203. [CrossRef]

14. Dosta, S.; Couto, M.; Guilemany, J.M. Cold spray deposition of a WC-25Co cermet onto Al7075-T6 and carbon steel substrates. Acta Mater. 2013, 61, 643-652. [CrossRef]

15. Couto, M.; Dosta, S.; Torrell, M.; Fernández, J.; Guilemany, J.M. Cold spray deposition of WC-17 and 12 Co cermets onto aluminum. Surf. Coat. Technol. 2013, 235, 54-61. [CrossRef]

16. Yang, G.-J.; Gao, P.-H.; Li, C.-X.; Li, C.-J. Mechanical property and wear performance dependence on processing condition for cold-sprayed WC-(nanoWC-Co). Appl. Surf. Sci. 2015, 332, 80-88. [CrossRef]

17. Al-Mangour, B.; Mongrain, R.; Irissou, E.; Yue, S. Improving the strength and corrosion resistance of 316L stainless steel for biomedical applications using cold spray. Surf. Coat. Technol. 2013, 216, 297-307. [CrossRef]

18. Lima, R.S.; Karthikeyan, J.; Kay, C.M.; Lindemann, J.; Berndt, C.C. Microstructural characteristics of cold-sprayed nanostructured WC-Co coatings. Thin Solid Films 2002, 416, 129-135. [CrossRef]

19. Kim, H.-J.; Lee, C.-H.; Hwang, S.-Y. Superhard nano WC-12\% Co coating by cold spray deposition. Mater. Sci. Eng. A 2005, 391, 243-248. [CrossRef]

20. Xie, Y.; Yin, S.; Chen, C.; Planche, M.-P.; Liao, H.; Lupoi, R. New insights into the coating/substrate interfacial bonding mechanism in cold spray. Scr. Mater. 2016, 125, 1-4. [CrossRef]

21. Gao, P.-H.; Li, C.-J.; Yang, G.-J.; Li, Y.-G.; Li, C.-X. Influence of substrate hardness on deposition behavior of single porous WC-12Co particle in cold spraying. Surf. Coat. Technol. 2008, 203, 384-390. [CrossRef]

22. Gao, P.-H.; Li, C.-J.; Yang, G.-J.; Li, Y.-G.; Li, C.-X. Influence of substrate hardness transition on built-up of nanostructured WC-12Co by cold spraying. Appl. Surf. Sci. 2010, 256, 2263-2268. [CrossRef]

23. Ji, G.-C.; Wang, H.-T.; Chen, X.; Bai, X.-B.; Dong, Z.-X.; Yang, F.-G. Characterization of cold-sprayed multimodal WC-12Co coating. Surf. Coat. Technol. 2013, 235, 536-543. [CrossRef]

24. Li, C.-J.; Yang, G.-J.; Gao, P.-H.; Ma, J.; Wang, Y.-Y.; Li, C.-X. Characterization of nanostructured WC-Co deposited by cold spraying. J. Therm. Spray Technol. 2007, 16, 1011-1020. [CrossRef]

25. Gao, P.-H.; Li, Y.-G.; Li, C.-J.; Yang, G.-J.; Li, C.-X. Influence of powder porous structure on the deposition behavior of cold-sprayed WC-12Co coatings. J. Therm. Spray Technol. 2008, 17, 742-749. [CrossRef]

26. Yin, S.; Xie, Y.; Cizek, J.; Ekoi, E.; Hussain, T.; Dowling, D.; Lupoi, R. Advanced diamond-reinforced metal matrix composites via cold spray: Properties and deposition mechanism. Compos. Part B Eng. 2017, 113, 44-54. [CrossRef]

27. Yin, S.; Wang, X.-F.; Li, W.-Y.; Jie, H.-E. Effect of substrate hardness on the deformation behavior of subsequently incident particles in cold spraying. Appl. Surf. Sci. 2011, 257, 7560-7565. [CrossRef]

28. Buyuk, M.; Kurtaran, H.; Marzougui, D.; Kan, C.D. Automated design of threats and shields under hypervelocity impacts by using successive optimization methodology. Int. J. Impact Eng. 2008, 35, 1449-1458. [CrossRef]

29. Criss, E.M.; Smith, R.J.; Meyers, M.A. Failure mechanisms in cobalt welded with a silver-copper filler. Mater. Sci. Eng. A 2015, 645, 369-382. [CrossRef] 
30. Meng, Q.; Guo, S.; Zhao, X.; Veintemillas-Verdaguer, S. Bulk metastable cobalt in fcc crystal structure. J. Alloys Compd. 2013, 580, 187-190. [CrossRef]

31. Milan, M.T.; Bowen, P. Tensile and Fracture Toughness Properties of SiCp Reinforced Al Alloys: Effects of Particle Size, Particle Volume Fraction, and Matrix Strength. J. Mater. Eng. Perform. 2004, 13, 775-783. [CrossRef]

32. Li, P.; Lee, P.D.; Maijer, D.M.; Lindley, T.C. Quantification of the interaction within defect populations on fatigue behavior in an aluminum alloy. Acta Mater. 2009, 57, 3539-3548. [CrossRef]

33. Bouafia, F.; Boualem, S.; Amin, M.M.E.; Benali, B. 3-D finite element analysis of stress concentration factor in spot-welded joints of steel: The effect of process-induced porosity. Comput. Mater. Sci. 2011, 50, 1450-1459. [CrossRef]

34. Yin, S.; Wang, X.; Suo, X.; Liao, H.; Guo, Z.; Li, W.; Coddet, C. Deposition behavior of thermally softened copper particles in cold spraying. Acta Mater. 2013, 61, 5105-5118. [CrossRef]

35. Assadi, H.; Gärtner, F.; Stoltenhoff, T.; Kreye, H. Bonding mechanism in cold gas spraying. Acta Mater. 2003, 51, 4379-4394. [CrossRef]

36. Yin, S.; Suo, X.; Xie, Y.; Li, W.; Lupoi, R.; Liao, H. Effect of substrate temperature on interfacial bonding for cold spray of Ni onto Cu. J. Mater. Sci. 2015, 50, 7448-7457. [CrossRef]

(C) 2018 by the authors. Licensee MDPI, Basel, Switzerland. This article is an open access article distributed under the terms and conditions of the Creative Commons Attribution (CC BY) license (http:/ / creativecommons.org/licenses/by/4.0/). 